\title{
PEMODELAN ALIRAN FLUIDA PADA MEDIA BERPORI
}

\author{
Alberto Triatmojo, Evi Noviani, Yudhi
}

\section{INTISARI}

\begin{abstract}
Air tanah adalah air yang mengalir melewati tanah dan batuan yang pada umumnya merupakan media berpori. Aliran air ini dapat dimodelkan ke dalam model matematika melalui penjabaran beberapa hukum fisika, seperti prinsip kontinuitas, hukum kekekalan massa, dan hukum Darcy. Pemodelan ini dapat dijadikan acuan untuk instansi seperti perusahaan air minum, pemadam kebakaran, rumah sakit dan instansi terkait untuk mencari letak strategis dari air tanah. Pada penelitian ini, diasumsikan fluida mengalir pada media berpori dengan kecepatan $v$, kondisi aliran fluida steady, fluidanya tak termampatkan, aliran laminar dan confined. Akibat dari adanya aliran air, maka sumur I akan terisi air dengan ketinggian air $h_{1}$. Daerah yang berjarak $\Delta L$ dari sumur I dengan ke tempat lainnya yang mempunyai ketinggian air $h_{2}$. Fluida yang mengalir pada media berpori mempunyai energi. Kemudian energi fluida dianalisis dan dihubungkan dengan head hidrolik. Aliran fluida dianalisis pada satu partikel fluida dengan menggunakan hukum kekekalan massa sehingga diperoleh persamaan Laplace. Persamaan Laplace dapat ditransformasikan ke koordinat bola dan dari persamaan Laplace yang telah ditransformasikan dapat diperoleh solusi persamaan Laplace yang disebut juga persamaan head hidrolik. Dari solusi persamaan Laplace dapat disimpulkan bahwa ketinggian air berbanding terbalik dengan jarak sumber dengan sumur, sehingga semakin jauh jarak sumber air dengan sumur semakin rendah ketinggian air.
\end{abstract}

Kata Kunci: media berpori, hukum Darcy, persamaan Laplace, head hidrolik.

\section{PENDAHULUAN}

Air tanah adalah air yang terdapat di dalam tanah atau batuan di bawah permukaan tanah. Air tanah menjadi sumber air utama untuk memenuhi kebutuhan pokok hidup banyak orang seperti air minum, rumah tangga, industri, irigrasi, pertambangan, perkotaan dan lainnya [1]. Air tanah diatur juga dalam peraturan pemerintahan, yaitu pada Peraturan Menteri ESDM Nomor 20 Tahun 2017 tentang Pedoman Penetapan Nilai Perolehan Air Tanah. Peraturan tersebut membahas tentang seberapa penting peranan air tanah untuk instansi-instansi seperti perusahaan air minum, rumah sakit, pemadam kebakaran dan instansi terkait lainnya.

Menurut Darcy, penurunan tinggi air akan terjadi jika lintasan media berpori yang dilewati air semakin panjang [2]. Tinggi air tanah pada media berpori dapat dimodelkan ke dalam bentuk matematika. Pemodelan air tanah dapat dibentuk menurut kondisi dari aliran air dan sekitarnya. Pada pemodelan ini diperlukan beberapa hukum fisika untuk mengidentifikasi kondisi aliran air, media porinya beserta lingkungan sekitarnya. Hukum fisika yang dipakai antara lain hukum kekekalan massa, persamaan kontinuitas dan hukum Darcy. Pemodelan aliran air pada media berpori juga melibatkan persamaan diferensial pada matematika. Jika aliran air tanah ditinjau melalui persamaan hukum Darcy dan prinsip kontinuitas menghasilkan persamaan diferensial parsial yang berubah terhadap waktu dan tidak berubah terhadap waktu [3].

Manfaat pemodelan aliran fluida pada media berpori dapat digunakan untuk instansi-instansi seperti perusahaan air minum, rumah sakit, pemadam kebakaran dan instansi terkait lainnya untuk menentukan letak strategis keberadaan air tanah. Oleh karena itu, di dalam penelitian ini mengkaji model matematika dari aliran fluida pada media berpori dan mengkaji penyelesaian dari model aliran 
fluida pada media berpori. Batasan masalah dari penelitian ini yaitu kasus aliran fluida pada media berpori dalam hal ini adalah aliran air tanah dengan kondisi aliran fluida steady dimana aliran air tidak berubah terhadap waktu, fluidanya tak termampatkan (incompresible), tidak mengalami turbulensi pada aliran (laminar) dan akuifer dari media berpori diasumsikan terbatas di atas dan di bawah (confined).

\section{PENGGAMBARAN KASUS ALIRAN FLUIDA PADA MEDIA BERPORI}

Misalkan fluida mengalir dengan kecepatan $v$ di dalam tanah yang mempunyai 2 lapisan yaitu tanah dengan lapisan kedap air dan lapisan media berpori. Media berpori mempunyai pori-pori dimana pori-pori tersebut mempunyai nilai porositas $\phi$. Nilai porositas adalah nilai dari tingkat kemampuan air untuk melewati media berpori. Fluida tidak dapat mengalir melalui lapisan kedap air, sehingga fluida akan mengalir melalui media berpori atau disebut juga akuifer. Tinjau Gambar 1, akibat dari adanya aliran air, pada suatu tempat (Sumur I) akan terisi air dengan ketinggian air $h_{1}$. Di daerah lain berjarak $\Delta L$ dari Sumur I terdapat sumur lain (Sumur II) dengan ketinggian air $h_{2}$.

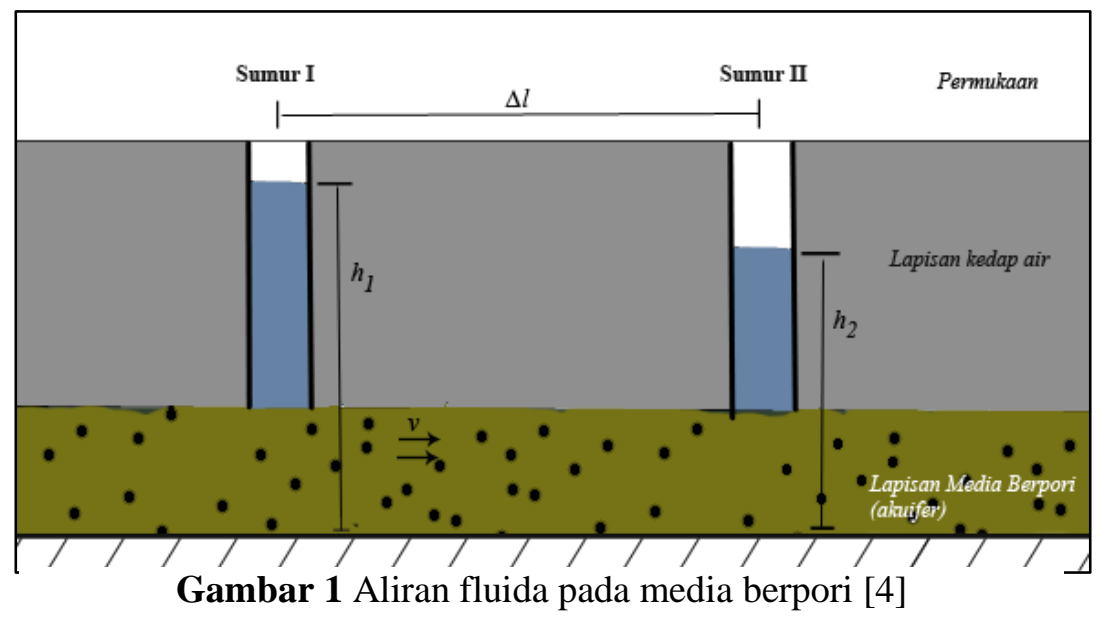

Pada penelitian ini membentuk model aliran air yang sesuai skema pada Gambar 1. Pembentukan model fluida pada media berpori digunakan beberapa hukum fisika, yaitu hukum kekekalan massa, hukum Darcy dan prinsip kontinuitas. Langkah pertama dalam pemodelan akan ditinjau tentang energi yang terlibat dalam aliran fluida.

\section{ENERGI FLUIDA DALAM MEDIA BERPORI}

Fluida dalam media berpori mempunyai 3 energi dalam bentuk energi mekanik, energi termal, dan energi kimia. Penelitian ini diasumsikan bahwa temperatur konstan, sehingga aliran air hanya dipengaruhi oleh energi mekanik saja. Dalam kondisi alam ditemui bahwa energi yang menggerakkan air adalah energi potensial atau energi gravitasi dan energi tekanan. Energi total pada media berpori adalah penjumlahan dari energi kinetik, energi potensial, dan energi tekanan, dapat ditulis:

$$
E=E_{k}+E_{p}+E_{T}
$$

dengan

E : Energi keseluruhan $\left(\mathrm{kg} \mathrm{m}^{2} / \mathrm{s}^{2}\right)$

$E_{k} \quad:$ Energi kinetik $\left(\mathrm{kg} \mathrm{m}^{2} / \mathrm{s}^{2}\right)$

$E_{p} \quad$ : Energi potensial $\left(\mathrm{kg} \mathrm{m}^{2} / \mathrm{s}^{2}\right)$

$E_{T} \quad$ : Energi eksternal $\left(\mathrm{kg} \mathrm{m}^{2} / \mathrm{s}^{2}\right)$.

Energi terjadi pada aliran fluida sehingga energi keseluruhan dijadikan energi keseluruhan persatuan volume, yang diperoleh sebagai berikut: 


$$
E_{V}=\frac{1}{2} \rho_{w} v^{2}+\rho_{w} g z+P
$$

dengan

$E_{V} \quad$ : Energi keseluruhan persatuan volume $\left(\mathrm{kg} / \mathrm{m} \mathrm{s}^{2}\right)$

$\rho_{w} \quad$ : Massa jenis fluida $\left(\mathrm{kg} / \mathrm{m}^{3}\right)$

$v: \operatorname{Kecepatan}(\mathrm{m} / \mathrm{s})$

$g \quad:$ Gravitasi $\left(\mathrm{m} / \mathrm{s}^{2}\right)$

$Z \quad$ : Ketinggian dari dasar media berpori menuju sebuah titik partikel aliran fluida yang ditinjau $(m)$

$P \quad:$ Tekanan hidrostatis $\left(\mathrm{kg} / \mathrm{m} \mathrm{s}^{2}\right)$.

Persamaan (2) diubah menjadi energi keseluruhan persatuan berat, sebagai berikut:

$$
E_{F}=\frac{\frac{1}{2} v^{2}}{g}+z+\frac{P}{\rho_{w} g},
$$

dengan $E_{F}$ merupakan energi keseluruhan persatuan berat $(m)$.

Energi total fluida dalam media berpori persatuan berat disebut juga head hidrolik. Head hidrolik merupakan variabel penting dalam menganalisa aliran air dalam media berpori. Kecepatan yang terjadi pada aliran air tanah sangat lambat sehingga kecepatan diabaikan. Sehingga didapat suatu persamaan sebagai berikut:

$$
h=z+\frac{P}{\rho_{w} g},
$$

dengan $h$ merupakan head hidrolik $(m)$

Fluida mengalir melalui media berpori hanya dipengaruhi oleh tekanan hidrostatis. Tekanan hidrostatis secara matematis dapat dituliskan sebagai berikut:

$$
P=\rho_{w} g h_{p}
$$

sehingga

$$
h_{p}=\frac{P}{\rho_{w} g},
$$

dengan $h_{p}$ merupakan kedalaman dari permukaan menuju aliran fluida pada titik tertentu yang ditinjau $(m)$. Persamaan (5) disubstitusikan ke Persamaan (4), sehingga persamaan dapat ditulis sebagai berikut:

$$
h=z+h_{p} .
$$

Persamaan (6) memberi suatu informasi keterkaitan hubungan head hidrolik dengan aliran fluida yang mengalir di suatu titik. "Keterkaitan dapat dilihat dari Gambar (2) berikut:

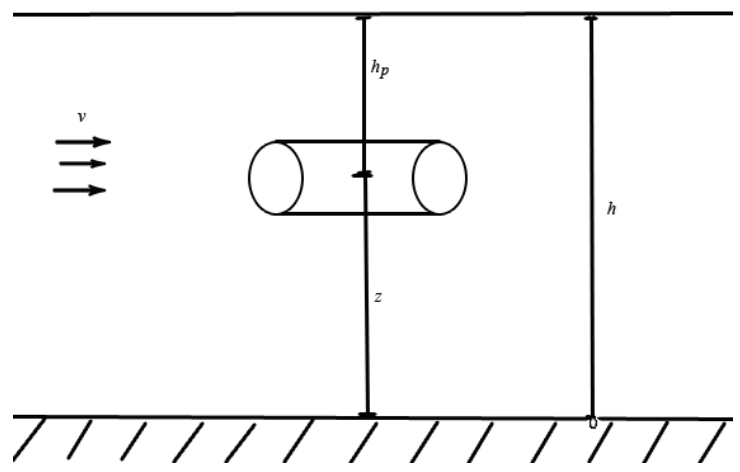

Gambar 2 Peninjauan pada satu partikel media berpori [4] 
Satu partikel fluida yang mengalir dalam media berpori mempunyai head hidrolik yang ekuivalen dengan tinggi permukaan air dan berlaku juga untuk partikel lainnya [4]. Akibatnya setiap partikel fluida yang melalui media berpori mempunyai head hidrolik dengan persamaan yang sama.

\section{PEMODELAN PERSAMAAN ALIRAN FLUIDA PADA MEDIA BERPORI}

Hukum kekekalan massa berbunyi massa yang masuk ke dalam suatu partikel benda akan sama dengan massa yang keluar dari benda. Fluida yang melalui media berpori dapat digambarkan dalam bentuk tiga dimensi, penggambaran dari fluida yang melalui media berpori dapat dilihat pada Gambar 3 berikut:

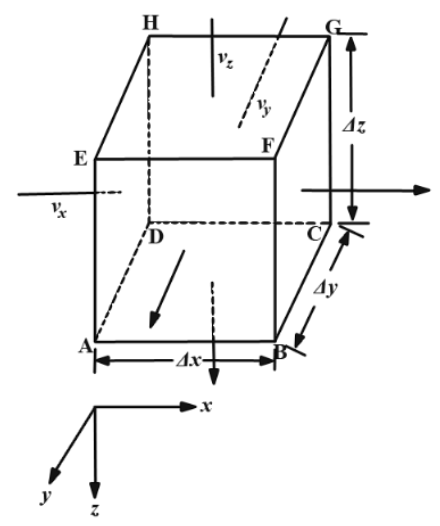

Gambar 3 Sistem koordinat volume kontrol pada satu partikel [5]

Kecepatan air yang melalui akuifer disimbolkan dengan $v$. Massa jenis merupakan perbandingan dari massa dengan volume, dapat dituliskan sebuah persamaan sebagai berikut:

$$
\begin{aligned}
\rho_{w} & =\frac{m}{V} \\
m & =\rho_{w} V \\
m & =\rho_{w} \Delta x \Delta y \Delta z,
\end{aligned}
$$

dengan

$m$ : Massa partikel aliran fluida $(\mathrm{kg})$

$V \quad$ : Volume partikel aliran fluida $\left(\mathrm{m}^{3}\right)$

$\Delta x \quad$ : Selisih jarak aliran air pada sumbu $\mathrm{X}(m)$

$\Delta y \quad$ : Selisih jarak aliran air pada sumbu $\mathrm{Y}(m)$

$\Delta z \quad$ : Selisih jarak aliran air pada sumbu $\mathrm{Z}(m)$.

Peninjauan fluida yang melalui beberapa bidang terdapat istilah laju inflow dan laju outflow. Laju inflow adalah laju massa air yang masuk ke suatu bidang, sedangkan laju outflow adalah laju massa yang keluar dari bidang. Peninjauan dilakukan dari fluida yang melalui bidang $y z$, sedemikian sehingga dimisalkan dibutuhkan waktu air untuk melalui sepanjang $\Delta x$. Jika Persamaan (6) dibagi dengan $t_{x}$, maka didapat persamaan :

$$
\frac{m}{t_{x}}=\rho_{w} \frac{\Delta x}{t_{x}} \Delta y \Delta z
$$

dengan $t_{x}$ merupakan waktu yang dibutuhkan fluida untuk melalui sepanjang $\Delta x(s)$.

Misalkan $v_{m_{\text {inx }}}=\frac{m}{t_{x}}$ dan $v_{x}=\frac{\Delta x}{t_{x}}$. Laju inflow melalui bidang ADHE dapat dinyatakan dengan $v_{m_{\text {inx }}}$ dan laju air yang masuk dan laju air yang spesifik arah $x$ dinyatakan dengan $v_{x}$, sehingga diperoleh :

$$
v_{m_{\text {inx }}}=\rho_{w} v_{x} \Delta y \Delta z
$$


$v_{m_{\text {inx }}}:$ Laju inflow pada sumbu $\mathrm{X}(\mathrm{kg} / \mathrm{s})$

$v_{x}:$ Kecepatan aliran fluida pada sumbu $\mathrm{X}(\mathrm{m} / \mathrm{s})$.

Selain itu juga untuk mendapat persamaan laju outflow bidang BCGF $v_{m_{\text {outx }}}$ juga dapat dilihat dari Gambar 3, sehingga membentuk persamaan:

$$
v_{m_{\text {outx }}}=\rho_{w} v_{x} \Delta y \Delta z+\frac{\partial\left(\rho_{w} v_{x}\right)}{\partial x} \Delta x \Delta y \Delta z,
$$

dengan $v_{m_{\text {outx }}}$ merupakan laju outflow pada sumbu X $(\mathrm{kg} / \mathrm{s})$.

Persamaan (9) didapat dari penjumlahan laju inflow dengan perubahan laju massa air yang masuk melalui bidang ADHE ke bidang BCGF. Selisih antara laju inflow dan laju outflow pada Sumbu X adalah

$$
\Delta v_{m_{x}}=\frac{\partial\left(\rho_{w} v_{x}\right)}{\partial x} \Delta x \Delta y \Delta z
$$

dengan $\Delta v_{m_{x}}$ merupakan selisih antara laju inflow dan laju outflow pada Sumbu X $(\mathrm{kg} / \mathrm{s})$.

Selain peninjauan dari bidang $y z$, peninjauan juga dilakukan pada bidang $x z$ dan bidang $x y$. Sama seperti mencari selisih antara laju inflow dan laju outflow pada sumbu $\mathrm{X}$, untuk mencari selisih antara laju inflow dan laju outflow pada sumbu Y dan selisih antara laju inflow dan laju outflow pada sumbu Z digunakan juga cara yang sama. Berikut selisih antara laju inflow dan laju outflow pada sumbu Y dan selisih antara laju inflow dan laju outflow pada sumbu Z:

$$
\Delta v_{m_{y}}=\frac{\partial\left(\rho_{w} v_{y}\right)}{\partial y} \Delta x \Delta y \Delta z
$$

dan

$$
\Delta v_{m_{z}}=\frac{\partial\left(\rho_{w} v_{z}\right)}{\partial z} \Delta x \Delta y \Delta z
$$

dengan

$\Delta v_{m_{y}}:$ Selisih antara laju inflow dan laju outflow pada Sumbu Y $(\mathrm{kg} / \mathrm{s})$

$\Delta v_{m_{z}}$ : Selisih antara laju inflow dan laju outflow pada Sumbu Z $(\mathrm{kg} / \mathrm{s})$

$v_{y} \quad$ : Kecepatan aliran fluida pada sumbu $\mathrm{Y}(\mathrm{m} / \mathrm{s})$

$v_{z} \quad$ : Kecepatan aliran fluida pada sumbu Z $(\mathrm{m} / \mathrm{s})$.

Persamaan (10), Persamaan (11), dan Persamaan (12) dijumlahkan menjadi total selisih laju inflow dan outflow yang dituliskan sebagai berikut:

$$
\Delta v_{t o t}=\left(\frac{\partial\left(\rho_{w} v_{x}\right)}{\partial x}+\frac{\partial\left(\rho_{w} v_{y}\right)}{\partial y}+\frac{\partial\left(\rho_{w} v_{z}\right)}{\partial z}\right) \Delta x \Delta y \Delta z
$$

dengan $\Delta v_{\text {tot }}$ adalah total selisih antara laju inflow dan laju outflow $(\mathrm{kg} / \mathrm{s})$.

Massa air per satuan volume total akuifer adalah hasil kali antara massa jenis dengan porositas. Porositas merupakan volume air per satuan volume akuifer. Total selisih antara laju inflow dan laju outflow persatuan volume dapat ditulis $\frac{\partial\left(\rho_{w} \phi\right)}{\partial t}$. Sehingga persamaan adalah sebagai berikut:

$$
\frac{\partial\left(\rho_{w} \phi\right)}{\partial t}=\left(\frac{\partial\left(\rho_{w} v_{x}\right)}{\partial x}+\frac{\partial\left(\rho_{w} v_{y}\right)}{\partial y}+\frac{\partial\left(\rho_{w} v_{z}\right)}{\partial z}\right) \Delta x \Delta y \Delta z
$$

Aliran fluida dalam penelitian ini menggunakan konsep hukum Darcy yang ditulis sebagai berikut:

$$
v=-K\left(\frac{d h}{d L}\right)
$$

dengan 
$K \quad:$ Konduktivitas hidrolik $(\mathrm{m} / \mathrm{s})$

$L \quad$ : Panjang lintasan $(m)$.

Aliran fluida menggunakan konsep hukum Darcy dan aliran steady state sehingga tidak dipengaruhi oleh waktu. Sehingga dari asumsi tersebut didapat persamaan berikut:

$$
\frac{\partial^{2} h}{\partial x^{2}}+\frac{\partial^{2} h}{\partial y^{2}}+\frac{\partial^{2} h}{\partial z^{2}}=0
$$

Persamaan (16) juga disebut sebagai persamaan Laplace. Persamaan (16) ditransformasikan dari koordinat kartesius menjadi koordinat bola. Pembentukan transformasi Persamaan (16) dapat dilihat pada Gambar 4 berikut:

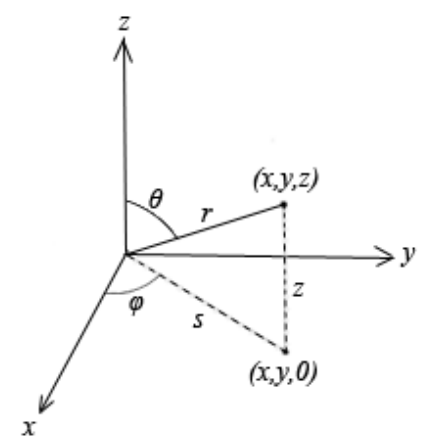

Gambar 4 Pembentukan transformasi dari koordinat Kartesius menjadi koordinat bola [5]

Pemisalan dapat disesuaikan dengan Gambar 4 dengan $x=s \cos \varphi, y=s \sin \varphi, z=r \cos \theta$, dan $s=r \sin \theta$. Dari pemisalan didapat operator diferensial sebagai berikut:

$$
\frac{\partial^{2}}{\partial x^{2}}+\frac{\partial^{2}}{\partial y^{2}}+\frac{\partial^{2}}{\partial z^{2}}=\frac{\partial^{2}}{\partial r^{2}}+\frac{2}{r} \frac{\partial}{\partial r}+\frac{1}{r^{2}} \frac{\partial^{2}}{\partial \theta^{2}}+\frac{1}{r^{2}} \cot \theta \frac{\partial}{\partial \theta}+\frac{1}{r^{2} \sin ^{2} \theta} \frac{\partial^{2}}{\partial \varphi^{2}}
$$

Persamaan Laplace merupakan persamaan dengan fungsi harmonik. Fungsi harmonik pada Persamaan (16) terjadi pada ruang dimensi tiga. Fungsi harmonik pada ruang dimensi tiga tidak dipengaruhi oleh pergerakan rotasi, maka suatu persamaan diturunkan terhadap sudut menjadi nol [5]. Sehingga operator diferensial pada Persamaan (17) berubah menjadi:

$$
\frac{\partial^{2}}{\partial x^{2}}+\frac{\partial^{2}}{\partial y^{2}}+\frac{\partial^{2}}{\partial z^{2}}=\frac{\partial^{2}}{\partial r^{2}}+\frac{2}{r} \frac{\partial}{\partial r}
$$

Operator diferensial dari Persamaan (18) digunakan untuk merubah Persamaan (16) menjadi:

$$
\frac{\partial^{2} h}{\partial x^{2}}+\frac{\partial^{2} h}{\partial y^{2}}+\frac{\partial^{2} h}{\partial z^{2}}=\frac{\partial^{2} h}{\partial r^{2}}+\frac{2}{r} \frac{\partial h}{\partial r}=0
$$

Persamaan (19) diselesaikan menggunakan persamaan diferensial sehingga membentuk persamaan:

dengan

$$
h=-\frac{C_{1}}{r}+C_{2}
$$

$C_{1}$ dan $C_{2}$ : Konstanta

$h \quad:$ head hidrolik $(m)$

$r \quad:$ Jarak sumur $(m)$.

\section{CONTOH KASUS ALIRAN FLUIDA PADA MEDIA BERPORI}

Pengaplikasian data dari persamaan aliran air tanah di dapat dari Altunkaynak dan Sen [6] yang telah melakukan pengamatan aliran air tanah di daerah Usfan, Turki. Data penelitian dari Altunkaynak dan Sen [6] adalah $r_{1}=18 m, r_{2}=32 m, h_{1}=4,5 m$, dan $h_{2}=2,7 m$ dengan $r_{1}$ adalah jarak posisi awal dengan koordinat pertama, $r_{2}$ adalah jarak posisi awal dengan koordinat kedua, $h_{1}$ adalah ketinggian air pada media berpori di koordinat pertama, dan $h_{2}$ adalah ketinggian air pada media berpori 
di koordinat kedua. Letak sumur besar, koordinat sumur pertama $\mathbf{0}_{\mathbf{1}}$, dan koordinat sumur kedua $\mathbf{0}_{\mathbf{2}}$ dapat dilihat dari Gambar 5 berikut:

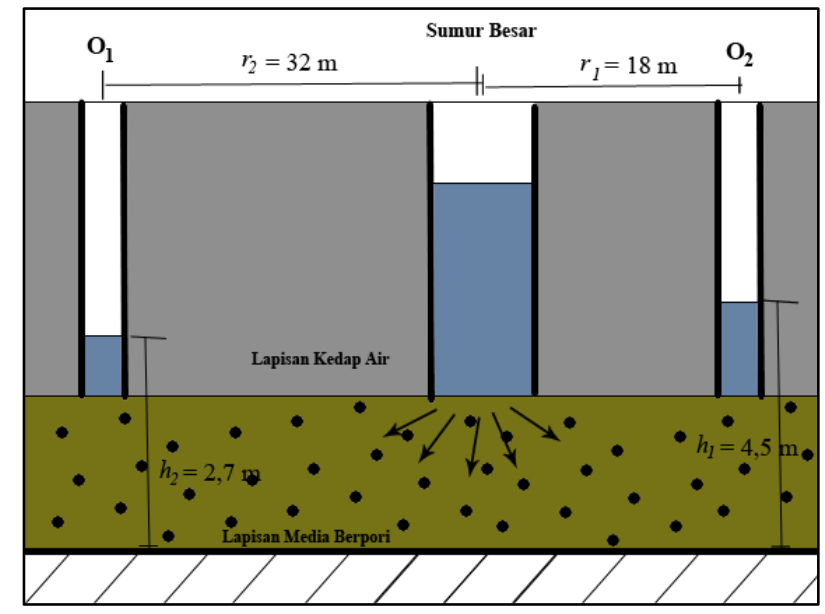

Gambar 5 Ilustrasi jarak sumur besar dengan koordinat 1 dan koordinat 2 beserta ketinggiannya

Pengaplikasian tersebut didapat sebuah persamaan head hidrolik khusus daerah Usfan yang dituliskan sebagai berikut:

$$
h=\frac{5184}{70 r}+\frac{27}{70} .
$$

Persamaan (21) dapat diketahui bahwa head hidrolik berbanding terbalik dengan jarak sumur sehingga semakin jauh jarak sumur, semakin menurun head hidrolik. Sama halnya yang diungkapkan Darcy bahwa semakin jauh jarak lintasan semakin menurun ketinggian air [2]. Grafik dari Persamaan (3.44) dapat dilihat pada Gambar 6 berikut:

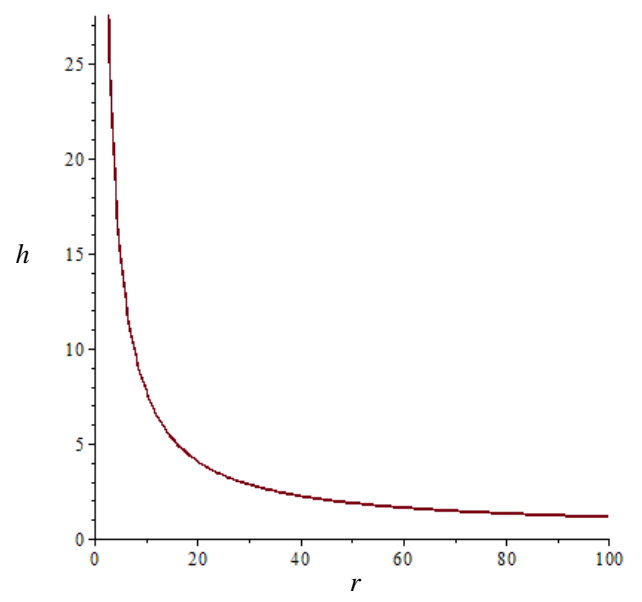

Gambar 6 Grafik solusi persamaan head hidrolik daerah Usfan

Grafik solusi persamaan yang dapat dilihat pada Gambar 6 mengalami penurunan head hidrolik disaat semakin jauh dari tempat air mengalir. Pernyataan ini sama seperti yang diungkap oleh Darcy bahwa semakin jauh lintasan yang dilalui air, semakin terjadi penurunan head hidrolik. 


\section{PENUTUP}

Fluida yang mengalir pada media berpori mempunyai energi. Energi yang mempengaruhi aliran fluida terdiri dari energi mekanik, energi termal dan energi kimia. Penelitian ini diasumsikan temperatur konstan, sehingga aliran air hanya dipengaruhi oleh energi mekanik. Energi mekanik adalah penjumlahan dari energi potensial, energi kinetik dan energi tekanan. Karena pergerakan air tanah yang sangat lambat maka diasumsikan bahwa kecepatan air tanah mendekati nol sehingga energi kinetik dari aliran fluida dapat diabaikan. Kemudian energi fluida dianalisis dan dihubungkan dengan head hidrolik.

Aliran fluida dianalisis pada satu partikel fluida dengan menggunakan hukum kekekalan massa. Aliran fluida ditinjau menggunakan aliran dimensi tiga sehingga diperoleh sebuah persamaan yang disubstitusikan sebuah persamaan dari hukum Darcy yang menghasilkan persamaan Laplace.

Persamaan Laplace yang telah diperoleh ditransformasi dari persamaan diferensial koordinat kartesius menjadi koordinat bola, sehingga diperoleh:

$$
\frac{\partial^{2} h}{\partial \mathrm{r}^{2}}+\frac{2}{r} \frac{\partial \mathrm{h}}{\partial \mathrm{r}}=0
$$

Setelah transformasi, kemudian dicari solusi persamaan aliran fluida pada media berpori yang dituliskan sebagai berikut:

$$
h=-\frac{1}{r} C_{1}+C_{2}
$$

dengan $h$ adalah head hidrolik, $C_{1}$ dan $C_{2}$ adalah konstanta dan $r$ adalah jarak sumur. Solusi dari persamaan Laplace model aliran air pada media berpori disebut juga persamaan head hidrolik. Persamaan head hidrolik dapat disimpulkan bahwa semakin jauh sumur dengan sumber air mengalir, semakin rendah ketinggian air.

\section{DAFTAR PUSTAKA}

[1] Rejekiningrum, P. Peluang Pemanfaatan Air Tanah Untuk Keberlanjutan Sumber Daya Air. Sumberdaya Lahan, III(2), pp. 85-96; 2009.

[2] Shekhar, Shashank . Darcy's Law. New Delhi: University of Delhi; 2017.

[3] Syahruddin, Muhammad Hamzah. Persamaan Aliran Air Dalam Media Berpori Sebagai Aliran Airtanah (Groundwater). Simposium Fisika Nasional 2014 (SFN XXVII), Volume XXVII; 2014.

[4] Fetter, Charles Willard. Applied Hydrogeology / C.W. Fetter,--4th ed. p. cm.. Edisi keempat. New Jersey: Prentice-Hall, Inc; 2001.

[5] Strauss, Walter A. Partial Differential Equation an Introdution. Edisi kedua. New Jersey: John Wiley and Sons, Inc; 2008.

[6] Altunkaynak, A. dan Sen, Z. Steady state flow with hydraulic conductivity change around large diameter wells. Hydrological Processes, Volume XXV, pp. 1778-1783; 2011.

\footnotetext{
ALBERTO TRIATMOJO : Jurusan Matematika FMIPA Untan, Pontianak alberto08220@gmail.com

EVI NOVIANI : Jurusan Matematika FMIPA Untan, Pontianak evi_noviani@math.untan.ac.id

YUDHI : Jurusan Matematika FMIPA Untan, Pontianak yudhi@math.untan.ac.id
} 
